\title{
ANALISIS MANAJEMEN RISIKO PENDISTRIBUSIAN ZAKAT PADA LAZNAS DAARUT TAUHIID PEDULI CABANG MALANG
}

\author{
Ismiyatun Nafi'ah \\ Departemen Ekonomi Syariah-Fakultas Ekonomi dan Bisnis-Universitas Airlangga \\ Email: ismiyatun-nafiah-feb15.web.unair.ac.id \\ Noven Suprayogi \\ Departemen Ekonomi Syariah-Fakultas Ekonomi dan Bisnis-Universitas Airlangga \\ Email: Noven.Suprayogi@feb.unair.ac.id
}

\begin{abstract}
:
The purpose of this researchis to find out the risk management of zakat distribution carried out by laznas Daarut Tauhiid Peduli Malang can increase the utilization of zakat.The method used in this research is an explanatory qualitative approach. The choice of the main focus in this research was based on the fact that the most impactful risk is the risk of misdirection (distribution) or inefficiency, so it will potentially decrease the reputation and trust of muzakki towards amil zakat institutions. The results of this research there are three points that are considered capable to influence the distribution of zakat such as dishonesty of prospective beneficiaries, inconsistent mustahik in giving reports, and the behavior of mustahik is not good. During the implementation, Daarut Tauhiid Peduli Malang can manage distribution risk so that it can increase the utilization of zakat.
\end{abstract}

Keywords: zakat, risk management, risk of zakat distribution, increased utilization of zakat, laznas Daarut Tauhiid Peduli Malang

\section{PENDAHULUAN}

Zakat memiliki potensi yang sangat besar untuk menunjang kesejahteraan masyarakat, maka pendayagunaan zakat selain untuk kebutuhan konsumtif jangka pendek dapat dialihkan menjadi zakat produktif yang bermanfaat untuk jangka panjang. Dalam UU nomor 23 tahun 2011 tentang pengelolaan zakat, mendayagunakan dana zakat secara produktif bertujuan agar manfaat dana zakat bisa dirasakan dalam jangka panjang dan juga diharapkan suatu saat hasil zakat produktif dapat merubah kondisi mustahik menjadi muzakki. Berdasarkan pertemuan perdana International Working Group on Zakat Core Principle (IWGZCP), disepakati bahwa identifikasi risiko dalam pengelolaan zakat merupakan hal yang sangat penting karena akan mempengaruhi kualitas pengelolaan zakat. Ada empat risiko yang sudah teridentifikasi yaitu risiko reputasi dan kehilangan muzakki, risiko pendistribusian , risiko operasional, serta risiko transfer antar negara.

Menurut Bank Indonesia (2016:130) risiko yang paling berdampak adalah risiko kegagalan pengelolaan dalam arti salah sasaran (pendistribusian) ataupun tidak efisien sehingga berpotensi pada turunnya reputasi dan kepercayaan muzakki terhadap lembaga amil zakat. Risiko salah sasaran (pendistribusian) bisa disebabkan oleh kurangnya data para

\footnotetext{
${ }^{1}$ Jurnal ini merupakan bagian dari skripsi dari Ismiyatun Nafi'ah, NIM: 041511433125 , yang diuji pada tanggal 22 Juli 2019.
} 
mustahik yang tergolong dalam delapan ashnaf, bisa juga karena kurang pahamnya lembaga amil zakat mengenai kriteria masing-masing dari delapan ashnaf dan bisa juga disebabkan karena amil zakat yang bertugas tidak amanah, akibatnya pendistribusian dana zakat tidak merata dan akan ada pihak-pihak yang terdholimi.

Dalam konteks ini, lembaga amil zakat harus dapat mengurangi risiko pendistribusian seperti posisi keuangan yang kurang sehat dan misalokasi kegiatan pendayagunaan. Manajemen risiko menjadi suatu keharusan bagi setiap perusahaan (Darmawi, 2008). Manajemen risiko merupakan bagian utama dari setiap manajemen strategis suatu lembaga atau organisasi. Daarut tauhiid Peduli merupakan lembaga amil zakat nasional yang pada tanggal 7 September 2018 meraih Penghargaan Baznas Award 2018 dengan kategori laznas dengan pendistribusian ZIS terbaik" dikutip dari republika.co.id (28 Desember 2018). Sebuah prestasi ini mampu memberikan gambaran manajemen risiko yang dilakukan oleh laznas DT Peduli terutama dalam risiko pendistribusian dana zakatnya.

Berdasarkan uraian diatas, maka rumusan masalah dalam penelitian adalah bagaimana manajemen risiko pendistribusian zakat pada lembaga amil zakat nasional Daarut Tauhid Peduli Malang dapat meningkatkan pendayagunaan zakat? Adapun Penelitian ini bertujuan untuk mengetahui manajemen risiko pendistribusian zakat pada lembaga amil zakat nasional Daarut tauhid Peduli Malang dapat meningkatkan pendayagunaan zakat.

\section{LANDASAN TEORI}

Menurut Arthur Williams dan Richard, M.H, risiko adalah suatu variasi dan hasil-hasil yang dapat terjadi selama periode tertentu. Menurut A. Abas Salim, risiko adalah ketidak tentuan (uncertainty) yang mungkin melahirkan peristiwa kerugian. Menurut Soekarto, risiko adalah ketidakpastian atas terjadinya suatu peristiwa. Ketidak pastian merupakan sunnatullah yang dihadapi manusia

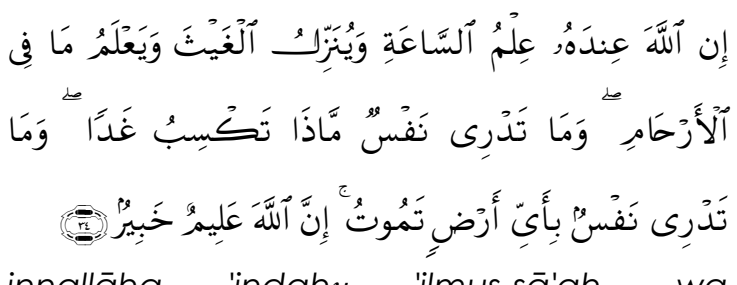

innallāha 'indahu 'ilmus-sā'ah, wa yunazzilul-gaīs, wa ya'lamu mā fil-ar-hām, wa mā tadrī nafsum māzā taksibu gadā, wa mā tadrī nafsum bi ayyi ardin tamut, innallāha 'alimun khabìr

Artinya : Sesungguhnya Allah, hanya pada sisi-Nya sajalah pengetahuan tentang hari Kiamat; dan Dia-lah yang menurunkan hujan, dan mengetahui apa yang ada dalam rahim. dan tiada seorangpun yang dapat mengetahui (dengan pasti) apa yang akan diusahakannya besok. dan tiada seorangpun yang dapat mengetahui di bumi mana Dia akan mati. Sesungguhnya Allah Maha mengetahui lagi Maha Mengenal. (QS. Luqman (31):34)

Manajemen risiko menurut Herman Darmawi (2016:19) adalah suatu usaha 
untuk mengetahui, menganalisis, serta mengendalikan risiko dalam setiap kegiatan perusahaan dengan tujuan untuk memperoleh efektifitas dan efisiensi yang lebih tinggi. Dalam buku Islamic Risk Management for Islamic Bank (2013) proses manajemen risiko adalah sistem yang komprehensif yang mencakup menciptakan lingkungan manajemen risiko yang tepat, menjaga efisien pengukuran risiko, mitigasi, dan proses monitoring, dan menetapkan pengaturan pengendalian internal yang memadai.

Penilaian risiko menggunakan model ISO dibentuk berdasarkan frekuensi kejadian yang mungkin terjadi (likelihood) dan dampak yang mungkin terjadi (impact). Klasifikasi penilaian risiko dengan melakukan penghitungan risiko dengan cara mengalikan potensi kejadian (likelihood) dengan besarnya dampak yang mungkin terjadi (impact), untuk mempermudah melakukan pengklasifikasian dari ragam risiko dapat dilihat pada tabel dibawah ini:

Tabel 1.

\section{Klasifikasi Penilaian Risiko ISO 9001:2015}

\begin{tabular}{|c|c|}
\hline \multicolumn{2}{|c|}{ Level of Risk } \\
\hline $\begin{array}{c}\text { Minimum- } \\
\text { Maximum }\end{array}$ & $\begin{array}{c}\text { Keterangan } \\
\text { (SR) }\end{array}$ \\
\hline $1-5$ & $\begin{array}{c}\text { Sangat rendah } \\
\text { Rendah (R) }\end{array}$ \\
\hline $6-10$ & Sedang (S) \\
\hline $11-15$ & Tinggi (T) \\
\hline $16-20$ & Sangat tinggi (ST) \\
\hline $21-25$ &
\end{tabular}

Sumber: Badan POM RI (2017)
Risiko pendistribusian zakat menurut Dyarini dalam jurnal yang berjudul manajemen risiko pengelolaan zakat (2017) adalah ketika terjadi tidak tepat sasaran dan tingkat keefisienan dan tingkat keefektivitasan penyaluran yang kurang. Risiko kurang tepat sasaran bisa disebabkan oleh kurangnya data para mustahik yang tergolong dalam delapan ashnaf, sedangkan risiko tingkat keefisienan dan tingkat keefektivitasan penyaluran yang kurang berkaitan dengan fungsi dana yang disalurkan atau dapat dikatakan dengan risiko pendayagunaan dana zakat yang kurang tepat.

Pendayagunaan dana zakat diarahkan pada tujuan pemberdayaan melalui berbagai program yang berdampak positif bagi masyarakat khususnya umat Islam yang kurang beruntung. Menurut Rosyidi dan Widiastuti dalam jurnalnya yang berjudul model pendayagunaan zakat produktif oleh lembaga zakat dalam meningkatkan pendapatan mustahik (2015:96) hasil dari pemberdayaan adalah masyarakat penerima dana bantuan zakat produktif tersebut telah meningkat pendapatannya (hasil dari pengelolaan usaha), lancar dalam pembayaran angsuran, dan kesanggupan dalam berinfaq/shodaqah.

\section{METODE PENELITIAN}

Penelitian ini menggunakan metode penelitian yaitu studi kasus eksplanatori. Menurut Umar (1999:36) penelitian eksplanatori adalah penelitian yang bertujuan untuk menganalisis 
hubungan-hubungan antara satu variabel dengan variabel lainnya atau bagaimana suatu variabel mempengaruhi variabel lainnya. Dengan metode penelitian studi kasus eksplanatori maka penelitian ini bertujuan untuk menganalisis secara mendalam tentang manajemen risiko pendistribusian zakat Daarut Tauhiid Peduli Malang Malang dapat meningkatkan pendayagunaan zakat. Penelitian ini menggunakan unit analisis data yang terdiri dari:

1. Identifikasi risiko pendistribusian zakat lembaga amil zakat nasional Daarut Tauhiid Peduli Malang

2. pengukuran risiko pendistribusian zakat lembaga amil zakat nasional Daarut Tauhiid Peduli Malang

3. pengendalian risiko pendistribusian zakat lembaga amil zakat nasional Daarut Tauhiid Peduli Malang

4. pemantauan risiko pendistribusian zakat lembaga amil zakat nasional Daarut Tauhiid Peduli Malang.

Keempat unit di atas, akan dijadikan sebagai bahan untuk menjawab dari rumusan masalah, yaitu "Bagaimana Manajemen Risiko Pendistribusian zakat Daarut Tauhiid Peduli Malang dapat meningkatkan pendayagunaan zakat?"

\section{Teknik Pengumpulan Data}

Pada penelitian ini akan melakukan wawancara dengan kepala kantor cabang Malang dan pegawai yang berkaitan langsung dengan pendistribusian dana zakat dengan garis besar bahasannya adalah :1) proses manajemen risiko pendistribusian yang dilakukan lembaga amil zakat Daarut Tauhiid Peduli Malang mulai dari analisis risiko hingga pengambilan keputusannya, 2) penjelasan mengenai standar indikator mustahik, efektifitas dan efisiensi pendistribusian dana, batas waktu pendistribusian, dan lainnya yang diterapkan dalam pengelolaan zakat laznas DT Peduli Malang. Serta dengan melakukan pengambilan data dari lembaga dalam bentuk laporan tahunan, prosedur pelaksanaan pendistribusian, profil lembaga, dan lain-lain yang diperoleh dari laznas DT Peduli Malang.

\section{Teknik Validasi Data}

Penelitian ini menggunakan triangulasi sumber yaitu membandingkan dan mengecek balik derajat kepercayaan suatu informasi yang diperoleh melalui waktu dan alat yang berbeda dalam penelitian kualitatif (Patton 1987:331). Triangulasi sumber dapat dilakukan dengan cara:

1. Membandingkan hasil wawancara kepala cabang DT Peduli Malang dengan hasil wawancara pegawai pendistribusian DT Peduli Malang

2. Membandingkan hasil wawancara kepala cabang dan pegawai pendistribusian DT Peduli Malang dengan isi dokumen yang berkaitan

\section{Teknik Analisi Data}

Dalam penelitian ini, peneliti menggunakan metode analisis data menurut Miles dan Huberman (dalam Sugiono, 2012) mengemukakan bahwa aktivitas dalam analisis data kualitatif dilakukan secara interaktif dan 
berlangsung secara terus menerus sampai tuntas, sehingga datanya sudah jenuh. Aktivitas dalam analisis data yaitu :

1. Reduksi data

$$
\text { Mereduksi data berarti }
$$

merangkum, memilah hal-hal yang pokok, memfokuskan pada hal-hal yang penting, mecari tema dan polanya, dengan demikian data yang telah di reduksi akan memberikan gambaran yang lebih jelas dan mempermudah peneliti untuk mengumpulkan data selanjutnya, dan mencari bila diperlukan. Reduksi data dapat dibantu dengan peralatan elektronik seperti computer mini, dengan memberikan kode pada aspek-aspek tertentu (Sugiono, 2012).

\section{Penyajian data}

Langkah selanjutnya dalam analisis data kualitatif setelah mereduksi data adalah penyajian data, dalam penelitian kualitatif penyajian data bisa dilakukan dalam bentuk uraian singkat, bagan, hubungan antar kategori dan sejenisnya, dalam hal ini Miles dan Huberman (dalam Sugiono,2012) menyatakan yang paling sering digunakan untuk menyajikan data dalam penelitian kualitatif adalah dengan teks yang bersifat naratif, dengan menyajikan data maka akan memudahkan untuk memahami apa yang terjadi, merencanakan kerja selanjutnya berdasarkan apa yang telah di pahami tersebut (Miles dan Huberman, dalam Sugiono,2012).

3. Penarikan kesimpulan dan verifikasi Verifikasi dilakukan karena kesimpulan awal yang dikemukakan masih bersifat sementara, dan akan berubah bila tidak ditemukan bukti-bukti yang kuat yang mendukung pada pengumpulan data berikutnya, tetapi apabila kesimpulan yang dikemukakan pada tahap awal, didukung oleh buktibukti yang valid dan konsisten saat peneliti kembali ke lapangan untuk mengumpulkan data, maka kesimpulan yang dikemukakan merupakan kesimpulan yang kredibel, dalam penelitian ini yaitu pada awal peneliti mengadakan penelitian di laznas DT Peduli Malang dengan bertambahnya data hingga mendapatan kesimpulan sementara melalui verifikasi dilakukan secara terus menerus dengan melihat bukti valid yang ada, maka akan diperoleh kesimpulan yang bersifat menyeluruh.

\section{HASIL DAN PEMBAHASAN}

Tabel 2.

Konsep Risiko

\begin{tabular}{|c|c|c|c|}
\hline No & Domain & Sub-Domain & Kesimpulan/Penjelasan \\
\hline 1. & $\begin{array}{l}\text { Konsep Risiko } \\
\text { Pendistribusian } \\
\text { Zakat }\end{array}$ & Definisi & $\begin{array}{l}\text { konsep risiko pendistribusian zakat adalah } \\
\text { kegagalan laz dalam menyalurkan dana } \\
\text { zakat ke delapan ashnaf yang disebabkan } \\
\text { karena ketidak sesuaian informasi yang } \\
\text { diperoleh dari calon penerima manfaat } \\
\text { dengan kondisi lapangan dan juga }\end{array}$ \\
\hline
\end{tabular}




\begin{tabular}{|c|c|c|c|}
\hline & & & disebabkan oleh sistem. \\
\hline & & Sumber Risiko & $\begin{array}{l}\text { Internal: Risiko yang berasal dari lembaga, } \\
\text { misalnya kegagalan dalam memverifikasi } \\
\text { data. Eksternal: Risiko yang berasal diluar } \\
\text { lembaga, seperti oleh ketidakjujuran calon } \\
\text { penerima manfaat, tidak konsistennya } \\
\text { mustahik dalam memberikan laporan, } \\
\text { perilaku mustahik yang kurang baik. }\end{array}$ \\
\hline 2. & $\begin{array}{l}\text { Identifikasi Risiko } \\
\text { Pendistribusian } \\
\text { Zakat }\end{array}$ & Penyebab risiko & $\begin{array}{l}\text { Identifikasi risiko Daarut Tauhid Peduli cabang } \\
\text { Malang terdiri atas: risiko pendistribusian yang } \\
\text { disebabkan oleh ketidakjujuran calon } \\
\text { penerima manfaat, tidak konsistennya } \\
\text { mustahik dalam memberikan laporan, } \\
\text { perilaku mustahik yang kurang baik. }\end{array}$ \\
\hline \multirow[t]{3}{*}{3.} & $\begin{array}{l}\text { Penilaian Risiko } \\
\text { Pendistribusian } \\
\text { Zakat }\end{array}$ & $\begin{array}{l}\text { Ketidakjujuran } \\
\text { calon penerima } \\
\text { manfaat }\end{array}$ & $\begin{array}{l}\text { Risiko ini minim terjadinya sehingga penilaian } \\
\text { yang dilakukan menujukkan frekuensi } 1 \text { yang } \\
\text { berarti hampir tidak pernah terjadi tetapi } \\
\text { memliki dampak yang tinggi sehingga } \\
\text { mendapatkan nilai } 4 \text {, sehingga menghasilkan } \\
\text { score akhir } 4 \text { (sangat rendah). }\end{array}$ \\
\hline & & $\begin{array}{l}\text { Tidak } \\
\text { konsistennya } \\
\text { mustahik dalam } \\
\text { memberikan } \\
\text { laporan }\end{array}$ & $\begin{array}{l}\text { Penilaian yang dilakukan menunjukkan } \\
\text { frekuensi } 1 \text { yang berarti hampir tidak pernah } \\
\text { terjadi dan dampak } 2 \text { yang berarti } \\
\text { mempunyai dampak rendah, sehingga } \\
\text { menghasilkan score } 2 \text { (sangat rendah). }\end{array}$ \\
\hline & & $\begin{array}{l}\text { Perilaku mustahik } \\
\text { yang kurang } \\
\text { baik }\end{array}$ & $\begin{array}{l}\text { Penilaian yang dilakukan menunjukkan } \\
\text { frekuensi } 1 \text { yang berarti hampir tidak pernah } \\
\text { terjadi dan dampak } 2 \text { yang berarti } \\
\text { mempunyai dampak rendah, sehingga } \\
\text { menghasilkan score } 2 \text { (sangat rendah). }\end{array}$ \\
\hline \multirow[t]{3}{*}{4.} & $\begin{array}{l}\text { Pengendalian } \\
\text { atau } \\
\text { Penanganan } \\
\text { Risiko } \\
\text { Pendistribusian } \\
\text { Zakat }\end{array}$ & $\begin{array}{l}\text { Ketidakjujuran } \\
\text { calon penerima } \\
\text { manfaat }\end{array}$ & $\begin{array}{l}\text { Memperkuat prosedur penyeleksian calon } \\
\text { penerima manfaat, } \\
\text { survei berulang kali kepada calon penerima } \\
\text { manfaat (meng cross cek dokumen dengan } \\
\text { lapangan) }\end{array}$ \\
\hline & & $\begin{array}{l}\text { Tidak } \\
\text { konsistennya } \\
\text { mustahik dalam } \\
\text { memberikan } \\
\text { laporan }\end{array}$ & $\begin{array}{l}\text { Silaturrahmi langsung untuk mengontrol } \\
\text { perkembangan usaha mustahik, kontrol via } \\
\text { telfon }\end{array}$ \\
\hline & & $\begin{array}{l}\text { Perilaku mustahik } \\
\text { yang kurang } \\
\text { baik }\end{array}$ & $\begin{array}{l}\text { Memandirikan atau menghentikan bantuan } \\
\text { beasiswa. } \\
\text { Rencana kedepan akan melakukan } \\
\text { pendekatan kepada mustahik untuk } \\
\text { mengetahui alasan perilaku kurang baik } \\
\text { tersebut, dan membuat program untuk } \\
\text { penunjang. }\end{array}$ \\
\hline \multirow[t]{2}{*}{5.} & $\begin{array}{l}\text { Pemantauan } \\
\text { Risiko } \\
\text { Pendistribusian } \\
\text { Zakat }\end{array}$ & $\begin{array}{l}\text { Ketidakjujuran } \\
\text { calon penerima } \\
\text { manfaat }\end{array}$ & $\begin{array}{l}\text { Risiko dapat di cegah, tidak ada satupun } \\
\text { yang lolos dalam seleksi penerimaan } \\
\text { bantuan. }\end{array}$ \\
\hline & & $\begin{array}{l}\text { Tidak } \\
\text { konsistennya } \\
\text { mustahik dalam } \\
\text { memberikan }\end{array}$ & $\begin{array}{l}\text { Laporan sudah mulai tertata, meskipun } \\
\text { penerima manfaat memberikan laporannya } \\
\text { dua atau tiga bulan sekali tetapi lembaga } \\
\text { masih bisa mengontrol }\end{array}$ \\
\hline
\end{tabular}




\begin{tabular}{|c|c|c|c|}
\hline & & laporan & \\
\hline & & $\begin{array}{l}\text { Perilaku mustahik } \\
\text { yang kurang } \\
\text { baik }\end{array}$ & $\begin{array}{l}\text { Risiko ini dihilangkan, karena penerima } \\
\text { manfaat beasiswanya dihentikan. } \\
\text { Untuk mencegah agar risiko ini tidak terjadi } \\
\text { lagi adalah tergantung individu atau didikan } \\
\text { orang tua dan lingkungan sekitar, lembaga } \\
\text { belum ada program khusus untuk menangani } \\
\text { ini. }\end{array}$ \\
\hline \multirow[t]{4}{*}{6.} & Pendayagunaan & $\begin{array}{l}\text { Konsep } \\
\text { pendayagunaan } \\
\text { zakat }\end{array}$ & $\begin{array}{l}\text { Pemanfaatan dana zakat yang dapat } \\
\text { memberdayakan sehingga dapat } \\
\text { berdampak baik secara berkelanjutan }\end{array}$ \\
\hline & & $\begin{array}{l}\text { Hubungan } \\
\text { antara risiko } \\
\text { pendistribusian } \\
\text { zakat dengan } \\
\text { pendayagunaan } \\
\text { zakat }\end{array}$ & $\begin{array}{l}\text { Jika risiko dapat diminimalisir maka akan } \\
\text { dapat menarik donatur untuk } \\
\text { mengamanahkan dananya kemudian } \\
\text { program-program pendayagunaan akan di } \\
\text { dukung dari dana tersebut }\end{array}$ \\
\hline & & $\begin{array}{l}\text { Pendayagunaan } \\
\text { di DT Peduli } \\
\text { cabang Malang }\end{array}$ & $\begin{array}{l}\text { Pendayagunaan di laznas DT Peduli cabang } \\
\text { Malang masih dikatakan sebagai } \\
\text { pendayagunaan yang belum ideal. Karena } \\
\text { laznas DT Peduli cabang Malang belum bisa } \\
\text { memberikan output dari peralihan mustahik } \\
\text { ke muzakki, hanya saja mengantarkan } \\
\text { mereka agar bisa menjadi muzakki. }\end{array}$ \\
\hline & & $\begin{array}{l}\text { Zakat dikatakan } \\
\text { zakat yang } \\
\text { berdayaguna }\end{array}$ & $\begin{array}{l}\text { Ketika dana zakat bisa memberikan output } \\
\text { yang terlihat, yang bisa bermanfaat bagi } \\
\text { orang lain dan ketika mustahik sudah } \\
\text { sepenuhya menjadi muzakki tanpa bantuan } \\
\text { dari lembaga amil. }\end{array}$ \\
\hline
\end{tabular}

Sumber: Olah data peneliti

Berdasarkan hasil analisis penelitian tersebut, dapat ditarik beberapa pokok pembahasan dalam penelitian yang dilakukan, diantaranya:

\section{Konsep Risiko Pendistribusian Zakat}

Pendistribusian zakat merupakan penyaluran zakat kepada orang yang berhak menerima zakat (mustahik) baik secara konsumtif ataupun produktif, hal ini menjadi salah satu yang sangat penting bagi lembaga amil zakat khusunya laznas DT Peduli agar dana zakat dapat disalurkan kepada orang yang tepat. Risiko pendistribusian zakat terjadi karena kesalahan pendistribusian dana zakat untuk orang yang tidak berhak yang disebabkan oleh ketidak sesuaian informasi yang diperoleh dari calon penerima manfaat dengan kondisi lapangan dan juga disebabkan oleh sistem.

Konsep risiko pendistribusian zakat yang di angkat oleh laznas DT Peduli selaras dengan konsep risiko pendistribusian zakat menurut Dyarini dalam jurnal yang berjudul manajemen risiko pengelolaan zakat (2017) adalah ketika terjadi tidak tepat sasaran dan tingkat keefisienan dan tingkat keefektivitasan penyaluran yang kurang. Juga selaras dengan teori pendistribusian zakat yang terdapat dalam buku terbitan bank Indonesia yang berjudul pengelolaan zakat yang efektif bahwa 
lembaga amil zakat harus dapat mengurangi risiko pendistribusian seperti posisi keuangan yang kurang sehat dan misalokasi kegiatan pendayagunaan zakat (BI, 2016:142). Untuk meminimalisir kesalahan distribusi lembaga amil zakat harus mempunyai penilaian yang komprehensif terhadap calon penerima manfaat. Dalam QS At-Taubah ayat 60 menjelaskan bahwa pendistribusian dana zakat sudah ada ketentuan untuk penerimanya. Allah berfirman:

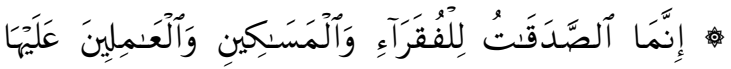

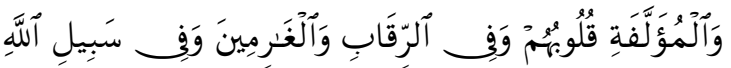

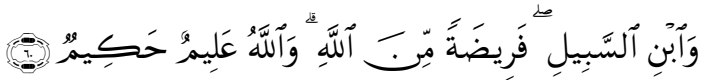
innamas-sadaqātu lil-fuqarāi walmasākīni wal-'āmilinna 'alaihā walmu'allafati qulubuhum wa fir-riqābi walgāriminna wa fi sabilillāhi wabnis-sabī, farīdatam minallāh, wallāhu 'alimun hakīm Artinya : Sesungguhnya zakat-zakat itu, hanyalah untuk orang-orang fakir, orangorang miskin, pengurus-pengurus zakat, Para mu'allaf yang dibujuk hatinya, untuk (memerdekakan) budak, orang-orang yang berhutang, untuk jalan Allah dan untuk mereka yang sedang dalam perjalanan, sebagai suatu ketetapan yang diwajibkan Allah, dan Allah Maha mengetahui lagi Maha Bijaksana. (QS. AtTaubah:60)

Ayat tersebut menjelaskan bahwa pendistribusian dana zakat sudah di tetapkan untuk siapa penerimanya, dana zakat hanya boleh di salurkan kepada delapan ashnaf. Lembaga amil zakat DT Peduli telah mempunyai prosedur yang cukup baik untuk penerimaan atau penolakan pengajuan bantuan agar dana zakat tidak tersalurkan kepada yang tidak memiliki hak menerima zakat.

\section{Penyebab Risiko Pendistribusian Zakat}

Berdasarkan teori identifikasi risiko dalam buku Islamic Risk Management for Islamic Bank (2013) disebutkan bahwa proses manajemen risiko meliputi tahapan identifikasi risiko yang dapat dilakukan dengan cara mengidentifikasi sumbersumber risiko dari lingkungan dan meneliti yang barangkali bisa muncul dari setiap sumber tersebut, mewawancarai manajer mengenai risiko-risiko yang di anggap penting bagi organisasi. Proses tersebut juga dilaksanakan oleh laznas DT Peduli, staff program atau pendistribusian selalu melakukan diskusi dengan kepala cabang DT Peduli Malang mengenai risiko-risiko pendistribusian zakat.

Berdasarkan hasil penelitian laznas DT Peduli cabang Malang terdapat tiga peristiwa yang dapat mempengaruhi pendistribusian zakat, antara lain: pertama ketidakjujuran calon penerima manfaat merupakan suatu sikap seseorang yang biasanya diungkapkan dengan ucapan atau perbuatan tidak sesuai dengan kenyataan, misalnya yang pernah terjadi pada laznas DT Peduli calon penerima manfaat mengajukan bantuan dengan mengurangi data atau memanipulasi data agar bantuannya bisa dicairkan. Allah berfirman dalam QS AnNahl ayat 105:

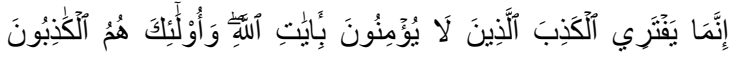
1.0 
Innamā yaftaril-każiballażina lā yu ‘minụna bi āyātillāh, wa ulāika humul-kāżibụn Artinya: "Sesungguhnya yang mengadaadakan kebohongan, hanyalah orangorang yang tidak beriman kepada ayatayat Allah, dan mereka itulah orangorang pendusta" (Q.S An-Nahl(16) 105)

Dalam ayat tersebut menjelaskan bahwa yang membuat kebohongan atau ketidakjujuran hanyalah orang-orang yang tidak beriman kepada ayat Allah dan termasuk golongan pendusta. Kedua tidak konsistennya mustahik dalam memberikan laporan merupakan sikap mustahik yang tidak melaporkan perkembangan kondisi usahanya pada waktu yang telah ditentukan. Ketiga perilaku mustahik yang kurang baik merupakan tindakan atau aktivitas dari penerima manfaat yang melakukan perilaku kurang pantas saat situasi tertentu.

\section{Hasil Penilaian Risiko Pendistribusian Zakat}

Penilaian risiko merupakan proses menggali informasi lebih dalam terhadap risiko yang telah diidentifikasi. Penilaian risiko dibutuhkan untuk dapat mengendalikan kemungkinankemungkinan yang dapat mengancam tercapainya tujuan (Arifin, 2009:272).

Berdasarkan identifikasi risiko pendistribusian zakat laznas DT Peduli, diperoleh hasil bahwa ketiga peristiwa atau kejadian yang dianggap mampu mempengaruhi pendistribusian zakat memiliki kategori tingkat yang sangat rendah. Selanjutnya, diklasifikasikan setiap peristiwa berdasarkan score akhir kemudian dapat diambil kesimpulan terkait risiko mana yang harus diprioritaskan. Sedangkan untuk memperoleh score akhir sendiri harus dilakukan analisis terkait dampak dan frekuensi kejadian. Hal itu dilakukan, agar dalam melakukan identifikasi risiko pendistribusian zakat tidak ada hal yang terlewatkan dan menyebabkan dampak yang buruk. Nilai risiko pendistribusian zakat yang disebabkan oleh ketidakjujuran calon penerima manfaat memperoleh nilai frekuensi 1 yang berarti risiko ini hampir tidak pernah terjadi tetapi dampak yang tinggi sehingga memperoleh nilai dampak 4, sehingga score yang didapat adalah 4. Kemudian untuk risiko pendistribusian yang disebabkan oleh tidak konsistennya mustahik dalam memberikan laporan memperoleh nilai frekuensi 1 yang berarti hampir tidak pernah terjadi dan dampak yang rendah sehingga memperoleh nilai dampak 2 sehingga score yang didapat adalah 2. Untuk risiko pendistribusian zakat yang disebabkan oleh perilkau mustahik yang kurang baik juga memperoleh nilai frekuensi 1 yang berarti hampir tidak pernah terjadi dan dampak yang rendah sehingga memperoleh nilai dampak 2 sehingga score yang didapat adalah 2 .

Nilai dampak terbesar berada pada risiko pendistribusian zakat yang disebabkan oleh ketidakjujuran calon penerima manfaat. Sedangkan untuk frekuensi ketiga risiko memperoleh nilai 1 yang berarti hampir tidak pernah terjadi. 
Secara ringkas, risiko-risiko pendistribusian dana zakat yang dimiliki laznas DT Peduli cabang Malang berada pada skala 2 sampai 4 dengan klasifikasi sangat rendah.

4. Pengendalian Risiko Pendistribusian Zakat

Menurut buku Islamic Risk Management for Islamic Bank (2013) implementasi penanganan atau pengendalian risiko terdiri atas menahan risiko, menghindari risiko, mencegah risiko, mengontrol risiko, dan mengalihkan risiko. Pengendalian risiko yang dilakukan oleh Laznas DT Peduli memilih untuk melakukan mitigasi yang terdiri dari pencegahan risiko dan menghindari risiko. Pengendalian risiko dilakukan dengan mencari tahu penyebab dari masingmasing risiko kemudian melakukan penyelesaian.

Risiko pendistribusian zakat yang disebabkan oleh ketidakjujuran calon penerima manfaat dapat di kendalikan dengan memperkuat prosedur penyeleksian melalui survei secara berulang kali dan meng cross cek dokumen dengan kondisi lapangan calon penerima manfaat, laznas DT Peduli juga mempunyai prosedur pelaksanaan program untuk layanan program yang didalamnya memuat alur proses layanan dan kriteria proses layanan. Kemudian untuk risiko pendistribusian zakat yang disebabkan oleh tidak konsisten mustahik dalam memberikan laporan dapat dikendalikan dengan melakukan silaturrahmi baik langsung maupun via telfon untuk mengontrol perkembangan usaha mustahik. Dalam Al-Qur'an Surat ArRum ayat 38 , Allah berfirman:

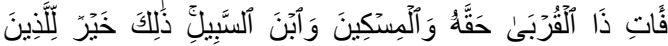

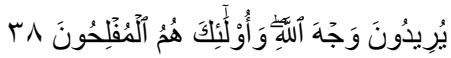

Fa āti żal-qurbā haqqahu wal-miskina wabnas-sabil, żālika khairul lillażīna yurīduna waj-hallāhi wa ulāiika humulmuflihun

Artinya:"Maka berikanlah kepada kerabat yang terdekat akan haknya, demikian (pula) kepada fakir miskin dan orangorang yang dalam perjalanan. Itulah yang lebih baik bagi orang-orang yang mencari keridhaan Allah; dan mereka itulah orangorang beruntung"'(Q.S Ar-Rum(38)30)

Dalam Ayat tersebut menjelaskan untuk memberikan hak kepada kerabat baik dengan sedekah atau zakat dengan makna lain juga melakukan silaturrahmi. Dengan silaturrahmi untuk melihat kondisi usaha mustahik, maka usaha mustahik bisa terkontrol dan mustahik bisa merasakan manfaat dari dana zakat.

Kemudian untuk risiko pendistribusian zakat yang disebabkan oleh perilaku mustahik yang kurang baik adalah dengan cara menghilangkan risiko yaitu menghentikan bantuan untuk mustahik. Untuk rencana kedepan laznas DT Peduli akan melakukan pendekatan kepada mustahik atau pihak yang bersangkutan agar dapat mengetahui alasan atau masalah mustahik, tentunya dibarengi dengan penambahan SDM juga agar dapat membantu menangani masalah-masalah lain yang mungkin terjadi. 
Dalam Islam upaya pengendalian tercermin dalam QS Al-Hasyr ayat 18, Allah berfirman:

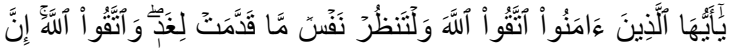

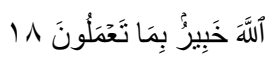

Yā ayyuhallażina āmanuttaqullāha waltanzur nafsum mā qaddamat ligad, wattaqullāh, innallāha khabìrum bimā ta'malun

Artinya: "Hai orang-orang yang beriman, bertakwalah kepada Allah dan hendaklah setiap diri memperhatikan apa yang telah diperbuatnya untuk hari esok (akhirat); dan bertakwalah kepada Allah, sesungguhnya Allah Maha Mengetahui apa yang kamu kerjakan" (Q.S Al-Hasyr (59):18)

Potongan ayat diatas dapat menjelaskan bahwa langkah yang diambil laznas DT Peduli merupakan salah satu hal yang diperbolehkan dalam Islam.

\section{Hasil Pengendalian Risiko}

\section{Pendistribusian Zakat}

Menurut buku Islamic Risk Management for Islamic Bank (2013) pemantauan merupakan evaluasi dari kerja proses penanganan risiko yang telah dilakukan dan digunakan sebagai dasar dalam penyusunan strategi penanganan risiko yang lebih baik dikemudian hari. Untuk hasil pengendalian risiko yang disebabkan oleh ketidakjujuran calon penerima manfaat yaitu risiko dapat di cegah, sehingga tidak ada satupun pengajuan yang lolos dalam seleksi penerimaan bantuan. Kemudian hasil pengendalian risiko pendistribusian zakat yang disebabkan oleh tidak konsistennya mustahik dalam memberikan laporan yaitu laporan sudah mulai tertata, meskipun penerima manfaat memberikan laporannya dua atau tiga bulan sekali tetapi lembaga masih bisa mengontrol usaha yang dijalankan mustahik. Untuk hasil pengendalian risiko pendistribusian zakat yang disebabkan oleh perilaku mustahik yang kurang baik yaitu risiko ini dihilangkan, dengan menghentikan beasiswa untuk penerima manfaat.

Jadi hasil dari pengendalian risiko pendistribusian zakat laznas DT Peduli ada risiko yang dapat dihilangkan dan ada yang diminimalisir, kemudian dari hasil tersebut akan merencanakan program pengendalian yang lebih baik untuk kedepannya, agar kemungkinankemungkinan buruk dikemudian hari bisa benar-benar dicegah dan teratasi.

\section{Hasil Pendayagunaan Zakat}

Menurut Rosyidi dan Widiastuti dalam jurnal yang berjudul model pendayagunaan zakat produktif oleh lembaga zakat dalam meningkatkan pendapatan mustahik (2015:96) hasil dari pemberdayaan adalah masyarakat penerima dana bantuan zakat produktif tersebut telah meningkat pendapatannya (hasil dari pengelolaan usaha), lancar dalam pembayaran angsuran, dan kesanggupan dalam berinfaq/shodaqah. Hal tersebut sudah terjadi di laznas DT Peduli, pendapat atau hasil usaha penerima bantuan terus mengalami peningkatan, seluruh penerima bantuan khususnya ekonomi dan pendidikan terbiasa berinfaq. Meskipun 
pendayagunaan yang dimiliki laznas

Daarut Tauhiid Peduli belum bisa dikatakan pendayagunaan yang ideal, karena belum bisa menghasilkan output yang terlihat yaitu bisa mentransformasi mustahik menjadi muzakki, hal tersebut guna untuk melatih mereka meyisihkan sebagian rezekinya untuk membantu yang membutuhkan meskipun mereka belum dikatakan sebagai muzakki yang sebenarnya.

\section{SIMPULAN}

Manajemen risiko pendistribusian zakat pada laznas Daarut Tauhiid Peduli di lakukan dengan cara mengindetifikasi sumber risiko baik eksternal maupun internal, dan risiko yang berhasil di identifikasi yaitu risiko pendistribusian zakat yang disebabkan oleh ketidakjujuran calon penerima manfaat, tidak konsistennya mustahik dalam memberikan laporan, serta perilaku mustahik yang kurang baik. Proses mitigasi risiko yang dilakukan dengan cara memperkuat prosedur penyeleksian calon penerima manfaat (cross cek dokumen dengan kondisi dilapangan), silaturrahmi baik langsung ke tempat usaha penerima manfaat maupun via telfon untuk mengontrol usaha mustahik, dan menghentikan bantuan bagi penerima manfaat yang perilakunya kurang baik. Sehingga risiko pendistribusian dapat dikurangi atau dikelola dan dapat meningkatkan pendayagunaan zakat

\section{DAFTAR PUSTAKA}

Aziz, Harry, dkk. 2017. Zakat \& Pemberdayaan. Surabaya : Pusat
Penerbit dan Percetakan Unair (AUP).

Driyarini, dan Jamilah Siti. 2017. Manajemen Risiko Pengelolaan Zakat. Ikraith- Humaniora, Vol 1, No 2.

Indonesia, Bank. 2016. Pengelolaan Zakat yang efektif : Konsep dan Praktik di beberapa negara. Jakarta : Departemen Ekonomi dan kevangan syariah - Bank Indonesia.

Indonesia, I. b. (2016). Tata Kelola manajemen Risiko perbankan. jakarta: PT Gramedia.

Khasanah, Umrotul. 2010. Manajemen Zakat Modern. Malang: UIN-Maliki Press

Meleong, Lexy J. 2011. Metodologi Penelitian Kualitatif. Bandung : PT Remaja Rosdakarya.

Nurul Huda dan Tjiptohadi Sawarjuwono. (2013). Akuntabilitas Pengelolaan Zakat Melalui Pendekatan Modifikasi Action Research . Jurnal Akuntansi Multiparadigma , 330507.

Satori, Komariah, dkk.2011. Metodologi Penelitian Kualitatif. Bandung: Alfabeta

Singarimbun, Masri dan Sofian. 1995. survey research methods. Jakarta: LP3ES Publishing.

Tika Widiastuti dan Suherman Rosyidi. (2015). Model Pendayagunaan Zakat Produktif Oleh Lembaga Zakat Dalam Meningkatkan Pendapatan Mustahik. JEBIS , 1. 
Nafi'ah, et al/Jurnal Ekonomi Syariah Teori dan Terapan Vol. 6 No. 10 Oktober 2019: 1995-2007; ANALISIS MANAJEMEN RISIKO PENDISTRIBUSIAN ZAKAT PADA LAZNAS DAARUT TAUHIID PEDULI CABANG MALANG

Umar, H. (1999). Metodologi Penelitian:

Jakarta: Gramedia Pustaka Utama.

Aplikasi dalam Pemasaran. 